\title{
The Fundamental Principle of Conservation of Physical Money: Its Violation and the Global Financial System Collapse
}

\author{
Murad Al-Shibli \\ Mechanical Engineering Department, College of Engineering, United Arab Emirates University, Al Ain, United Arab Emirates. \\ Email: malshibli@uaeu.ac.ae
}

Received December $8^{\text {th }}$, 2010; revised January $17^{\text {th }}, 2011$; accepted January $17^{\text {th }}, 2011$.

\begin{abstract}
Over the last two years the world has witnessed a financial tsunami that rocked the global financial systems. This paper presents the fundamental principle of conservation of physical money of the global financial system that guarantees its equilibrium and stability. Similar to the principle of conservation of mass-energy systems and based on the commodity money concept, then the physical money cannot be created from nullity nor can be destroyed. As a result, violation of such a system will lead to a deficit in the financial system which cannot be paid off. Additionally, violation of gold standard and the breakage of the Bretton Woods system are the reason behind the current world financial crisis. Paying non-zero interest on money loans will violate this principle as well. The international banking system is volatile and over-valued since it is based on the fractional banking technique that banks do not actually need to have the money to back up the deposits their clients have made into their accounts. Instead, the banks are required only to keep a small fraction of such deposits on hand. The world Today's reserves wealth of Gold, Silver and Copper is estimated by 8.63 Trillion US\$ compared to 4.3 Trillion US\$ in Currencies. Moreover The Bank of International Settlements (BIS) in Switzerland has recently reported that global outstanding derivatives have reached 1.14 quadrillion dollars: \$548 Trillion in listed credit derivatives plus $\$ 596$ trillion in notional OTC derivatives. Furthermore, by 2007 credit default swap total value has dramatically increased to an estimated $\$ 45$ trillion to $\$ 62$ trillion. Subprime mortgage crisis, credit crisis and banking closure all have resulted from the violation of conservation money. Taking into the account that the World's GDPs for all nations is approximately \$50 trillion and all of the asset value of the world is only \$190 Trillion, it can be seen easily that the over-valued $\$ 1140$ trillion financial derivatives will lead in the near future to the collapse of the international financial system similar to Iceland, Greece, Ireland crises and potentially in Spain, Portugal, and Italy.
\end{abstract}

Keywords: Conservation of Money, Fiat Money, Commodity Money, Gold Standard, Fractional Banking, Financial Derivatives, Credit Default Swap, Ponzi Scheme, Iceland Crisis, Greece Crisis

\section{Introduction}

In the last two years world has exposed to a financial tsunami waves that rocked the financial systems and nations all over the world. Many international banks and companies have bankrupted, nations has sank into a severe debts obligations. Layoff has almost cracked all sectors, millions of home mortgage have been closed, and millions of individuals had claimed bankruptcy. What a financial crisis has the Globe witnessed! What are the major reasons have caused it? This paper introduces the fundamental principle of conservation of physical money of the global financial system. Based on the commodity money concept, the physical money cannot be created from null nor can be destroyed. Violation of such a system will lead to a deficit in the financial system which cannot be paid off. The change in the net physical money in a financial system is equal to the amount of money transferred to the system (gained) minus the amount transferred out of it (lost). In other words, the law of conservation of money can be stated that the change in your current balance must be equal to the difference between the credits to your account and the debits to it. For this reason paying interest on money loans will violate this principle as well.

Additionally, violation of standard gold and the brea- 
kage of the Bretton Woods system are the reason behind the current world financial crisis. The international banking system is volatile since it is based on the fractional banking technique which means that banks do not actually have the money to back the deposits their clients have made into their accounts. Instead, the banks are required only to keep a small fraction of such deposits on hand. Moreover, data on the five-fold growth of derivatives to $\$ 1140$ trillion in five years comes from the most recent survey by the Bank of International Settlements in Switzerland. Additionally, subprime mortgage crisis, credit crisis and banking system run all have resulted from the violation of conservation money. Taking into the account that the World's GDPs for all nations is approximately $\$ 50$ trillion, it can be seen easily that the $\$ 1140$ trillion financial derivatives system will lead into the collapse of the international financial system.

This paper is organized as follows, in Section 2, basic definitions of money and standard gold are presented. Section 3 introduced the principle of conservation of money. Meanwhile, fractional banking system is described in Section 4, then Madoff (Ponzi) scheme is presented in Section 5. Section 6 shows how the financial derivatives are overvalued, in Section 7 credit default swap explained. Section 8 gives summarizes the mortgage crisis. Banking closures and US debt challenge are detailed in Sections 4 and 5, respectively. Greece and Iceland crises are discussed in Sections 6 and 7, respectively. Finally conclusions and recommendations are presented.

\section{Money and Gold Standard}

Money can be defined as is anything that is generally accepted as a payment for goods and services and repayment of debts. The main functions of money are distinguished as: a medium of exchange, a unit of account, a store of value, and occasionally, a standard of deferred payment. In 1875, economist William Stanley Jevons described what he called representative money as money that consists of token coins, or other physical tokens such as certificates, that can be reliably exchanged for a fixed quantity of a commodity such as gold or silver. The value of representative money stands in direct and fixed relation to the commodity that backs it, while not itself being composed of that commodity. Money originated as commodity money, but nearly all contemporary money systems are based on fiat money [1,2].

\subsection{Commodity Money}

Commodity money is money whose value comes from a commodity out of which it is made [3]. It is objects that have value in themselves as well as for use as money. Examples of commodities that have been used as me- diums of exchange include gold, silver, copper, salt. The system of commodity money eventually evolved into a system of representative money. This occurred because gold and silver merchants or banks would issue receipts to their depositors - redeemable for the commodity money deposited. Eventually, these receipts became generally accepted as a means of payment and were used as money. The gold standard, a monetary system where the medium of exchange are paper notes that are convertible into pre-set, fixed quantities of gold, replaced the use of gold coins as currency in the 17th-19th centuries in Europe. These gold standard notes were made legal tender, and redemption into gold coins was discouraged. By the beginning of the 20th century almost all countries had adopted the gold standard, backing their legal tender notes with fixed amounts of gold.

\subsection{Fiat Money}

Fiat money is without value as a physical commodity, and derives its value by being declared by a government to be legal tender; that is, it must be accepted as a form of payment within the boundaries of the country, for "all debts, public and private". Fiat money or fiat currency is money whose value is not derived from any intrinsic value or guarantee that it can be converted into a valuable commodity such as gold. Instead, it has value only by government order (fiat). Usually, the government declares the fiat currency (typically notes and coins from a central bank, such as the Federal Reserve System in the U.S.) to be legal tender, making it unlawful to not accept the fiat currency as a means of repayment for all debts, public and private [4].

\subsection{Gold Standard}

Gold Standard: prior to and during most of the 1800s, international trade was denominated in terms of currencies that represented weights of gold. Most national currencies at the time were in essence merely different ways of measuring gold weights (much as the yard and the meter both measure length and are related by a constant conversion factor). Hence some assert that gold was the world's first global currency. The emerging collapse of the international gold standard around the time of World War I had significant implications for global trade.

Not such a long time ago paper receipts for gold in storage were used as currency, and people would trade these receipts because it was more convenient than carrying around a lot of gold. Over time, those who held the gold and issued the receipts noticed that physical gold was seldom claimed even thought the receipts changed hands several times. The temptation to issue more receipts than the gold in storage became too large to resist, and fractional banking was invented. This allowed the issuers to 
charge interest and increase the amount of currency in circulation.

The scheme would work as long as everyone did not claim his or her gold at the same time. Those issuers (or later, banks) who egregiously abused the system suffered from bank-runs, in which receipt holders claimed their gold. Since there was not enough gold to cover all the outstanding receipts, only the first folks through the door would get any gold.

The system was based on the faith the public had in the gold receipts, with all issuers not being equal. So instead of the most conservative extreme of a gold standard without the ability of debt creation, let's consider what would happen if we accepted fractional banking, but just took away governments' right to seigniorage. If we add together all the currency in circulation (notes and coins) in the US, Japan, China, Britain, Canada, Russia, Australia and the European Union, converted to US dollars for simplicity, we arrive at \$2.6 trillion. These countries represent roughly $80 \%$ of the world's GDP so by extrapolation we can estimate that all the currency in circulation in the world today is approximately $\$ 3.25$ trillion.

Total historical gold production is about 5 billion ounces and most of it is still around. If all the gold in the world were converted to money to replace existing notes and coins, it would imply a gold price of $\$ 650$ an ounce. Back in the 1940s the United States alone held about one third of all the gold in the world and two thirds of the official reserves (gold held by governments). At the time, governments held approximately $50 \%$ of all the gold. If we assume that only half the gold in the world could be converted into money then it would imply a gold price of $\$ 1,300$ an ounce. The emerging collapse of the international gold standard around the time of World War I had significant implications for global trade.

\subsection{Bretton Woods System}

In the period following the Bretton Woods Conference of 1944, exchange rates around the world were pegged against the United States dollar, which could be exchanged for a fixed amount of gold. This reinforced the dominance of the US dollar as a global currency. The Bretton Woods system of monetary management established the rules for commercial and financial relations among the world's major industrial states in the mid 20th century. The chief features of the Bretton Woods system were an obligation for each country to adopt a monetary policy that maintained the exchange rate of its currency within a fixed value in terms of gold and the ability of the IMF to bridge temporary imbalances of payments [5].

\subsection{Nixon Shock}

Since the collapse of the fixed exchange rate regime and the gold standard and the institution of floating exchange rates following the Smithsonian Agreement in 1971, most currencies around the world have no longer been pegged against the United States dollar. However, as the United States remained the world's preeminent economic superpower, most international transactions continued to be conducted with the United States dollar, and it has remained the de facto world currency.

Then, on August 15,1971 the United States unilaterally terminated convertibility of the dollar to gold. This action created the situation whereby the United States dollar became the sole backing of currencies and a reserve currency for the member states. In the face of increasing financial strain, the system collapsed in 1971. The Nixon Shock was a series of economic measures taken by U.S. President Richard Nixon in 1971 including unilaterally canceling the direct convertibility of the United States dollar to gold that essentially ended the existing Bretton Woods system of international financial exchange. Because of the excess printed dollars, and the negative U.S. trade balance, other nations began demanding fulfillment of America's "promise to pay" - that is, the redemption of their dollars for gold [6].

Switzerland redeemed $\$ 50$ million of paper for gold in July. France, in particular, repeatedly made aggressive demands, and acquired \$191 million in gold, further depleting the gold reserves of the U.S. In May 1971, inflation-wary West Germany was the first member country to leave the Bretton Woods system unwilling to deflate the Deutsche Mark to prop up the dollar Still Switzerland withdrew the Swiss franc from the Bretton Woods system.

\subsection{Calls for New International Supernational Currrency}

Nowadays, many of the world's currencies are pegged against the dollar. Some countries, such as Ecuador, El Salvador, and Panama, have gone even further and eliminated their own currency (see dollarization) in favor of the United States dollar. The dollar continues to dominate global currency reserves, with $63.9 \%$ held in dollars, as compared to $26.5 \%$ held in euros.

On March 16, 2009, in connection with the April 2009 G20 summit, the Kremlin called for a supranational reserve currency as part of a reform of the global financial system. On March 24, 2009 People’s Bank of China, called for "creative reform of the existing international monetary system towards an international reserve currency," believing it would significantly reduce the risks of a future crisis and enhance crisis management capability. It is suggested that the IMF's Special Drawing Rights (a currency basket comprising dollars, euros, yen, and sterling) could serve as a super-sovereign reserve currency [7]. 
Figure 1 shows the most dominant currencies.

Indeed, on March 26, 2009, a UN panel called for a new global currency reserve scheme which with "greatly expanded SDR (Special Drawing Rights), with regular or cyclically adjusted emissions calibrated to the size of reserve accumulations, and could contribute to global stability, economic strength and global equity [8]. On March 30, 2009, at the Second South America-Arab League Summit in Qatar, Venezuelan President Hugo Chavez proposed the creation of the Petro as a supranational currency, in order to face the instability that the generation of fiat currency has caused in the world economy. The petro-currency would be backed by the huge oil reserves of the oil producing countries [9].

\subsection{Global Metalic Commodity Reserves}

The silver standard is a monetary system in which the standard economic unit of account is a fixed weight of silver. The silver specie standard was widespread from the fall of the Byzantine Empire until the 19th century. The total silver reserve is estimated by 569000 tons. Considering the latest price of silver as 25 US\$/Ounce, then the world wealth of silver is approximately 500 Billion US\$ (0.5 Trillion). It has been estimated that all the gold mined by the end of 2009 totaled 165,000 tonnes. At a price of US\$1300/oz just recently, one tonne of gold has a value of approximately US\$45.87 million. The total value of all gold ever mined would exceed US\$7.57 Trillion at that valuation [10]. A gold reserve is the gold held by a central bank or nation intended as a store of value and as a guarantee to redeem promises to pay depositors, note holders (paper money), or trading peers, or to secure a currency. At the end of 2004, central banks and investment funds held $19 \%$ of all above-ground gold as bank reserve assets. Iron total reserve is 730 billion tons. Copper total reserve is 2 billion tons. Zinc total reserve is 1.6 billion tons. Lead total reserve is 1.4 billion tons by US Geological Survey, Mineral Commodities Summaries 2006 [11]. The total copper wealth is estimated by 561 Billion US\$ (0.561 Trillion US\$). Table 1 lists the global metallic reserves.

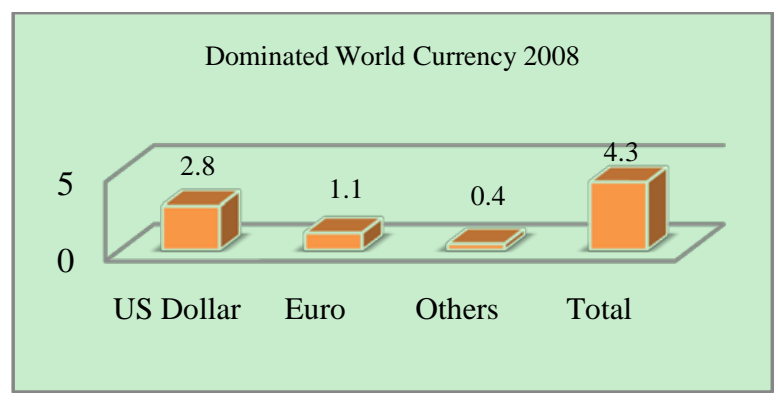

Figure 1. World dominating currencies.
Table 1. Global commodity reserves [12].

\begin{tabular}{ccc}
\hline Metal & Reserves Tonnes & Year Supplies left \\
\hline Aluminum & $32350 \mathrm{M}$ & 1027 years \\
Arsenic & $1 \mathrm{M}$ & 20 years \\
Antimony & $3.86 \mathrm{M}$ & 30 years \\
Cadmium & $1.6 \mathrm{M}$ & 70 years \\
Chromium & $779 \mathrm{M}$ & 143 years \\
Copper & $937 \mathrm{M}$ & 61 years \\
Gallium & $1000-1500 \mathrm{M}$ & $5-8$ years \\
Germanium & 500000 & 5 years \\
Gold & 89700 & 45 years \\
Hafnium & 1124 & 20 years \\
Indium & 6000 & 13 years \\
Lead & $144 \mathrm{M}$ & 42 years \\
Nickel & $143 \mathrm{M}$ & 90 years \\
Phosphorus & $49750 \mathrm{M}$ & 345 years \\
Platinum & 79840 & 360 years \\
Selenium & 170000 & 120 years \\
Silver & 569000 & 29 years \\
Tantalum & 153000 & 116 years \\
Thallium, & 650000 & 65 years \\
Tin & $11.2 \mathrm{M}$ & 40 years \\
Uranium & $3.3 \mathrm{M}$ & 59 years \\
Zinc & $460 \mathrm{M}$ & 46 years \\
\hline
\end{tabular}

\section{Fractional Banking System}

The banking system is called a fractional banking system because banks do not actually have the money to back the deposits their clients have made into their accounts. Instead, the banks are required only to keep a small fraction of such deposits on hand. When something with inherent value, such as gold, is used for money banks often go bankrupt under a fractional banking system since they do not have sufficient reserves to repay their depositors' money. However, in a fractional banking system based on fiat money banks need never go bankrupt, since the central bank can create an unlimited amount of new money to repay any demands from depositors. The limiting factor is only the public's acceptance of fiat money.

In the absence of a fractional banking system all the money in the system is physical money, such as notes and coins. We would know at all times exactly what the money supply is: it is the total of all the notes and coins. We would also know exactly what the inflation rate is: it is the rate at which the total amount of notes and coins increases. In such a system inflation can only occur by the creation of more physical notes and coins, whether it is fiat money or hard money, such as gold. However, in a fractional banking system defining what constitutes the money supply is not so simple, which is why it is such an enigma and why the real inflation rate is so obscure. While central banks can influence the money supply directly, most of the money that is created is actually created by commercial banks when they make loans to borrowers.

It is because our financial system is based on something called fractional reserve banking. When you go over to your local bank and deposit $\$ 100$, they do not keep your $\$ 100$ in the bank. Instead, they keep only a small fraction 
of your money there at the bank and they lend out the rest to someone else. Then, if that person deposits the money that was just borrowed at the same bank, that bank can loan out most of that money once again. In this way, the amount of "money” quickly gets multiplied. But in reality, only $\$ 100$ actually exists. The system works because we do not all run down to the bank and demand all of our money at the same time.

\section{Principle of Conservation of Physical Money}

Based on the former analysis, it can be seen that all commodity money has fixed reserves and conserved. For example the total world reserves of gold is 165000 tonnes. Meanwhile, reserve is 520000 tonnes. Since this commodity money is conserved then applying an interest rate on a given metal of the same entity will violate the principle of physical money conservation. As an example, assume that the total amount of gold is $Q$ then implementing an interest rate of $3 \%$ gold on that quantity $Q$ implies that $1.03 Q$ with an extra amount of $0.03 Q$ needed that the system cannot provide since the system has only quantity $Q$.

Assume now the overall financial fiat system $F$ is composed of $N$ financial sub-system $F 1, F 2, F 3, \cdots$, $F_{N}$, then

$$
F=F 1+F 2+F 3+\cdots+F_{N}=\text { const. }
$$

Let us consider that all subsystems are involved in a simple annual interest rate investment of $5 \%$ for a period of time of 1 year, then the future capital would be

$$
F_{\text {new }}=F(1+i t)=1.05 F
$$

It yields that the system shall provide $1.05 F$ money with $5 \%$ extra money out of its capacity, where the system can supply only $F$ fiat money. This fundamentally violates the conservation of physical money. For generalization let us take the rate of change (time-derivative) of the simple interest equation

$$
\frac{d F_{\text {new }}}{d t}=\frac{d F}{d t}+i=\frac{d \text { const. }}{d t}=0
$$

Since both $F_{\text {new }}$ and $F$ are conserved and their corresponding derivatives are zeros, yields that $i=0$. So for any physical money, zero interest should be enforced.

This paper presents the fundamental principle that the financial system must be based on so as to keep it in an equilibrium state. The change in the net physical money in a financial system is equal to the amount of money transferred to the system (gained) minus the amount transferred out of it (lost). In other words, the law of conservation of money can be stated that the change in your current balance must be equal to the difference between the credits to your account and the debits to it.
Based on this principle it can easily be seen that paying (or taking) interest on money loans will definitely violate such a fundamental principle.

Every single financial transaction on your account must obey this law, which is the fundamental law of accountancy and book keeping. This is based on the fact that money is discrete and countable. Every physical transaction obeys the law of conservation of mass-energy principle and presents the fundamental law of bookkeeping in nature. For any global financial system the gross physical money is conserved and equal to the sum of all sub-systems amounts. For a global human financial system, the physical money cannot be created from null nor can be destroyed. Violation of such a system will lead to a deficit in the financial system which cannot be paid off.

\section{Maddof (Ponzi) Scheme}

A Ponzi scheme is a fraudulent investment operation that pays returns to separate investors from their own money or money paid by subsequent investors, rather than from any actual profit earned [13]. The Ponzi scheme usually entices new investors by offering returns other investments cannot guarantee, in the form of short-term returns that are either abnormally high or unusually consistent. The system is destined to collapse because the earnings, if any, are less than the payments to investors. While the system eventually will collapse under its own weight, the example of Bernard Madoff illustrates the ability of a Ponzi scheme to delude both individual and institutional investors as well as securities authorities for long periods: Madoff's variant of the Ponzi Scheme stands as the largest financial investor fraud in history committed by a single person. Prosecutors estimate losses at Madoff's hand totaling $\$ 64.8$ billion.

\section{The 1140 Trillion Financial Derivatives}

Today there is a horrific derivatives bubble that threatens to destroy not only the U.S. economy but the entire world financial system as well. Basically, derivatives are financial instruments whose values depend upon or is derived from the price of something else. A derivative has no underlying value of its own. Moreover, both the hedgefund and the derivatives markets are almost totally unregulated, either by the U.S. government or by any other government worldwide and in recent years it has ballooned to such enormous proportions that it is almost hard to believe. Today, the worldwide derivatives market is approximately 80 times the size of the entire global economy. Well, the truth is that the danger that we face from derivatives is so great that Warren Buffet has called them "financial weapons of mass destruction".

What had happened is that a subsidiary of AIG had lost more than $\$ 18$ billion on Credit Default Swaps (deriva- 
tives) it had written, and additional losses from derivatives were on the way which could have caused the complete collapse of the insurance giant. So the U.S. government stepped in and bailed them out - all at U.S. taxpayer expense of course. But the AIG incident was actually quite small compared to what could be coming. The derivatives market has become so monolithic that even a relatively minor imbalance in the global economy could set off a chain reaction that would have devastating consequences.

A derivative is a financial instrument whose value depends on something else such as a share of stock, an interest rate, a foreign currency, or a barrel of oil, for example. One kind of derivative might be a contract that allows you to buy oil at a given price six months from now. But since we don't yet know how the price of oil will change, the value of that contract can be very hard to estimate. One method simply adds up the value of the assets the derivatives are based on. In other words, if my contract allows me to buy 50 barrels of oil and the current price is $\$ 100$, its "notional value” is said to be $\$ 5,000$. Since that's the value of the assets from which my contract derives. The "notional value" of the world's over-the-counter derivatives at the end of 2007, according to the Bank of International Settlements is around \$1140 trillion. Over the counter derivatives refer to contracts that are negotiated between two parties rather than through an exchange.

But the notional value is not usually a very good representation of what a contract might really be worth to the parties involved, or how much risk they are taking. And it isn't easily compared with other measures of financial wealth - after all, owning the right to buy \$5 000 worth of oil isn't the same as actually owning \$5 000 of oil. Within that $\$ 596$ trillion there are derivatives that effectively relate to the same assets [14]. For example, if you have a contract to buy Euros in January and I have one to buy Euros in April, we may end up buying the same currency, but its notional value will get counted twice.

The Bank of International Settlements, which seems to be the only institution that tracks the derivatives market, has recently reported that global outstanding derivatives have reached 1.14 quadrillion dollars: \$548 trillion in listed credit derivatives plus \$596 trillion in notional (over-the-counter) OTC derivatives. Figures $\mathbf{2}$ and $\mathbf{3}$ show the notional OTC derivatives, gross market value of the OTC derivatives, respectively. Two thirds of contracts by volume or $\$ 393$ trillion fell into the category of interest rate derivatives. Credit Default Swaps had a notional volume of $\$ 58$ trillion, seeing the sharpest relative increase after a volume of $\$ 43$ trillion a year earlier. Currency derivatives reached a volume of \$56 trillion.

Figures 4 and $\mathbf{5}$ display the notional OTC derivatives of foreign exchange and gross market value OTC foreign exchange, respectively. Unallocated derivatives with a notional amount of $\$ 71$ trillion. Data on the five-fold growth of derivatives to $\$ 596$ trillion in five years grew into a massive bubble comes from about $\$ 100$ trillion to \$596 trillion by 2007.

Over-the-counter (OTC) derivatives are contracts that are traded (and privately negotiated) directly between two parties, without going through an exchange or other intermediary. Products such as swaps, forward rate agreements, and exotic options are almost always traded in this way. The OTC derivative market is the largest market for derivatives, and is largely unregulated with respect to disclosure of information between the parties, since the OTC market is made up of banks and other highly sophisticated parties, such as hedge funds. Reporting of OTC amounts are difficult because trades can occur in private,

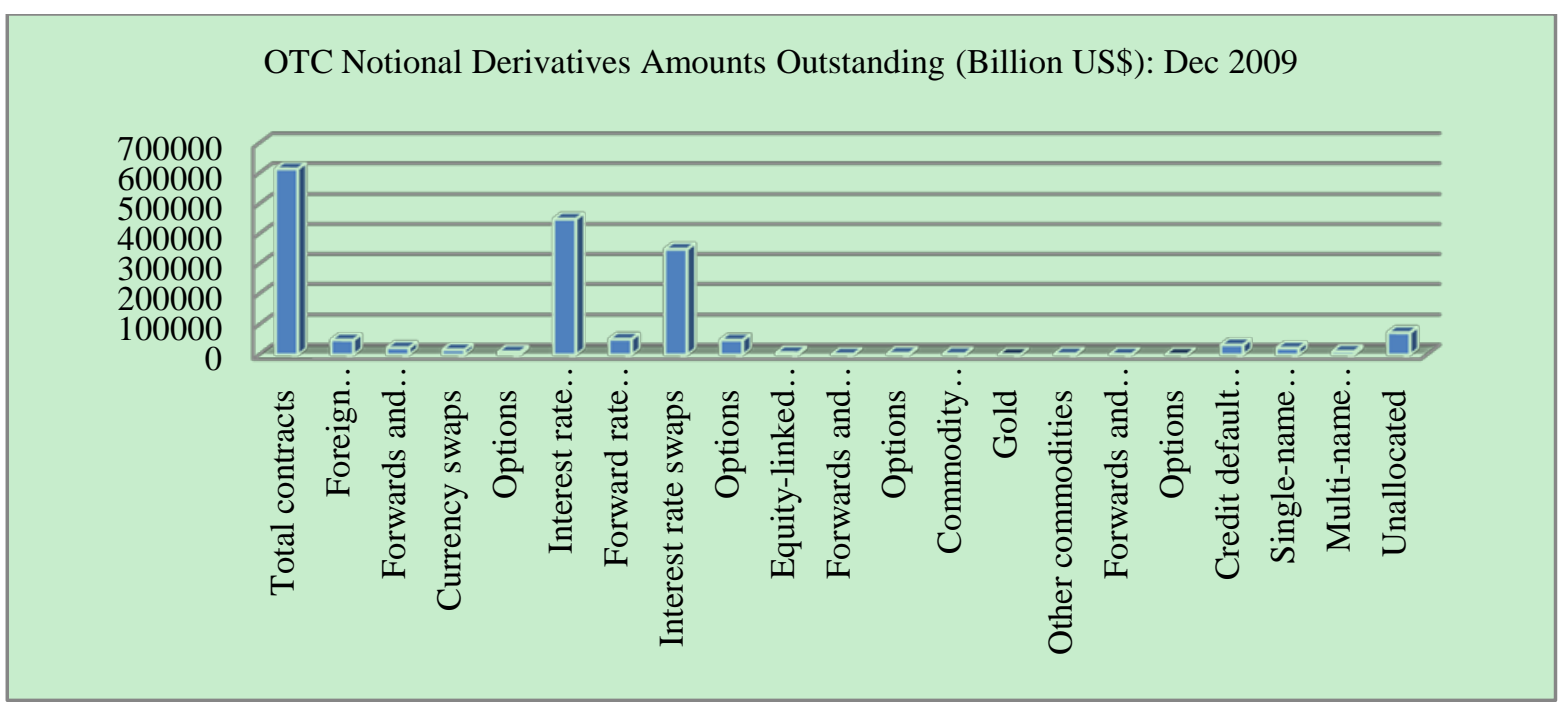

Figure 2. Notional over-the-counter derivatives (Trillion US\$) estimated by BIS. 


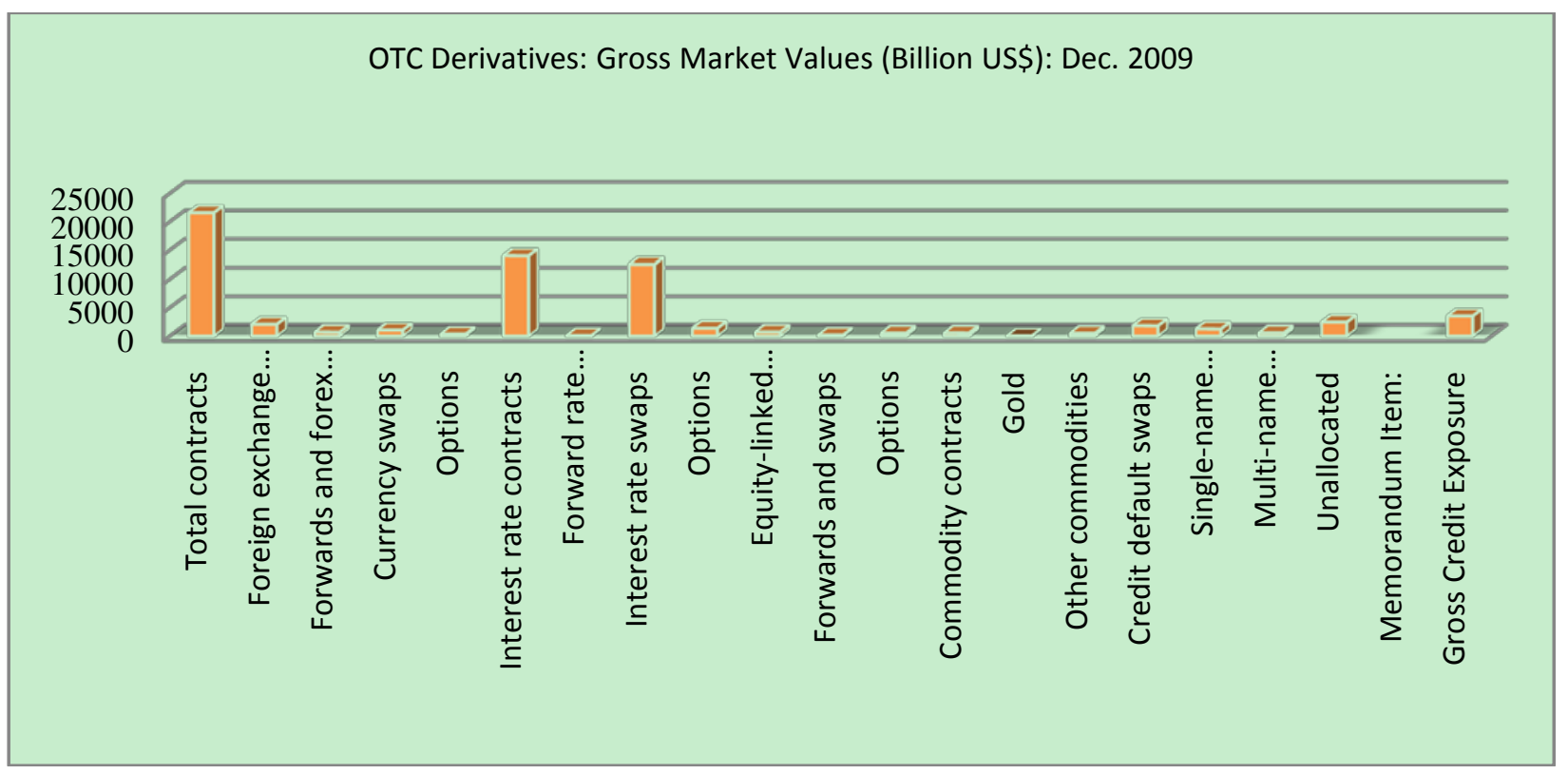

Figure 3. Gross market value over-the-counter derivatives (Trillion US\$) estimated by BIS.

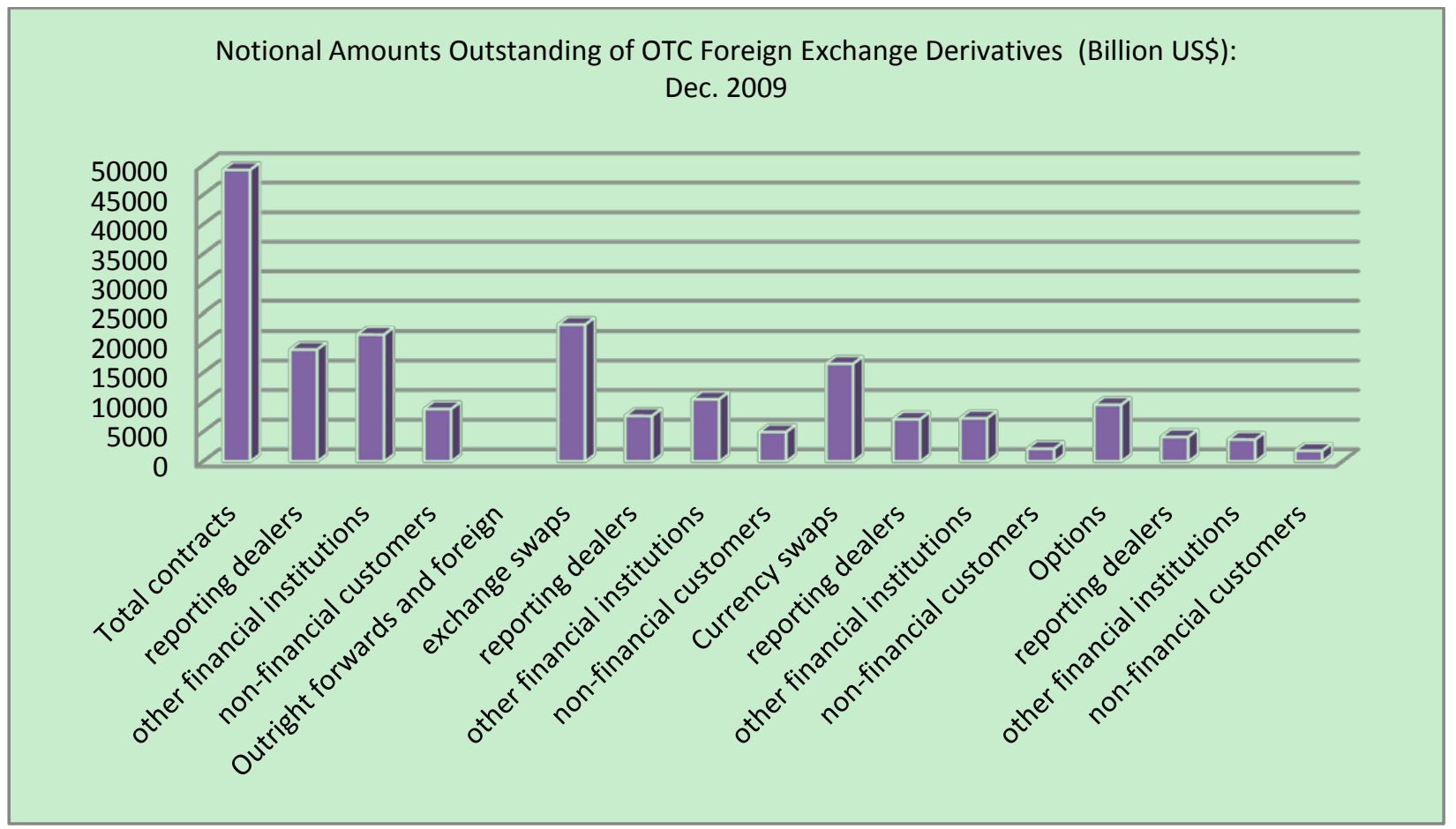

Figure 4. Notional over-the-counter derivatives of foreign exchange (trillion us\$) estimated by BIS.

without activity being visible on any exchange. According to the Bank for International Settlements, the total outstanding notional amount is $\$ 684$ trillion (as of June 2008). Of this total notional amount, $67 \%$ are interest rate contracts, $8 \%$ are credit default swaps (CDS), $9 \%$ are foreign exchange contracts, $2 \%$ are commodity contracts, $1 \%$ are equity contracts, and $12 \%$ are other. Because OTC deriv- atives are not traded on an exchange, there is no central counterparty.

The new derivatives bubble was fueled by five key economic and political trends:

- Increased corporate disclosures.

- Federal Reserve's cheap money policies created the subprime-housing boom. 


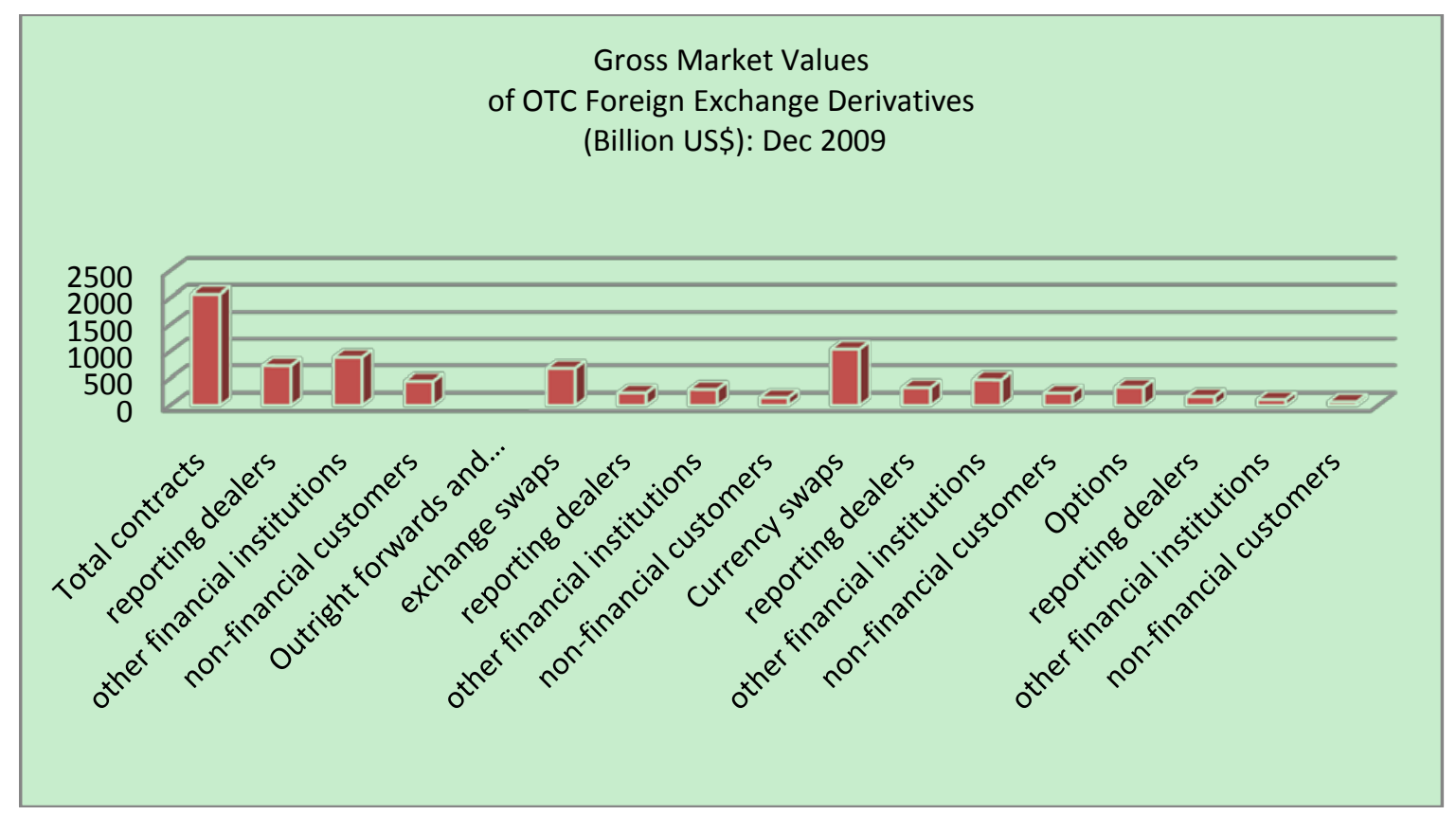

Figure 5. Gross market value over-the-counter derivatives (Trillion US\$) estimated by BIS.

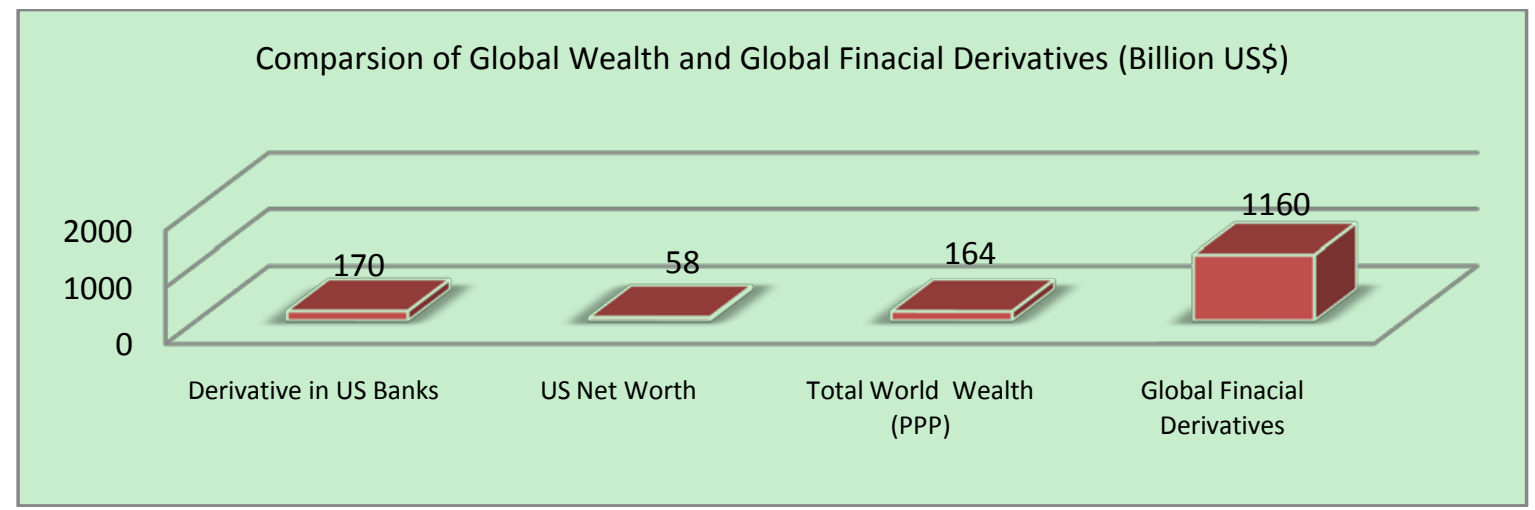

Figure 6. Total US derivatives and US wealth compared to total world wealth in year 2007.

- War budgets burdened the U.S. Treasury and future entitlements programs.

- Trade deficits with China and others destroyed the value of the U.S. dollar.

- Oil and commodity rich nations demanding equity payments rather than debt.

To grasp how significant this five-fold bubble increase is, let's put that $\$ 516$ trillion in the context of some other domestic and international monetary data (See Figure 6 and Table 2):

- U.S. annual gross domestic product is $\$ 15$ trillion.

- U.S. money supply is also about $\$ 15$ trillion.

- Current proposed U.S. federal budget is $\$ 3$ trillion.

- U.S. government's maximum legal debt is $\$ 9$ trillion.

- U.S. mutual fund companies about $\$ 12$ trillion.

- World’s GDPs for all nations is almost \$50 trillion.
- Unfunded Social Security and Medicare benefits \$50 trillion to \$65 trillion.

- Total value of the world's real estate is estimated at about $\$ 75$ trillion.

- Total value of world's stock and bond markets is more than $\$ 100$ trillion.

- BIS valuation of world's derivatives back in 2002 was about $\$ 100$ trillion.

- BIS 2007 valuation of the world's derivatives is now a whopping $\$ 596$ trillion.

\section{Credit Default Swap Crisis}

A credit default swap (CDS) is a swap contract in which the buyer of the CDS makes a series of payments to the seller and, in exchange, receives a payoff if a credit instrument (typically a bond or loan) undergoes a defined 
Table 2. Economy of the world [15].

\begin{tabular}{ll}
\hline $\begin{array}{l}\text { Population } \\
\text { (Feb 11, 2010) }\end{array}$ & $\mathbf{6 , 8 0 2 , 0 0 0 , 0 0 0}$ \\
\hline GDP (PPP) & US\$70.21 trillion (2009) \\
GDP (Currency) & $\$ 58.07$ trillion (2009) \\
GDP/capita (PPP) & $\$ 10,500$ \\
GDP/capita (Currency) & $\$ 7,178$ \\
$\begin{array}{l}\text { Annual growth of } \\
\text { per capita GDP (PPP) }\end{array}$ & $-0.8 \%$ (2009 est.) \\
People Paid Below \$2 per day & 3.25 billion ( 50\%) \\
Millionaires (US\$) & 9 million i.e. 0.15\% (2006) \\
Billionaires (US\$) & 793 (2009) \\
\hline
\end{tabular}

“Credit Event”, often described as a default (fails to pay). However the contract typically construes a Credit Event as being not only "Failure to Pay" but also can be triggered by the "Reference Credit" undergoing restructuring, bankruptcy, or even by having its credit rating downgraded. Credit default swaps may be used for emerging market bonds, mortgage backed securities, corporate bonds and local government bond [16,17].

The first credit default swap was introduced in 1995 by JP Morgan. By 2007, their total value has increased to an estimated $\$ 45$ trillion to $\$ 62$ trillion. Although since only $0.2 \%$ of investment companies default, the cash flow is much lower than this actual amount. J.P. Morgan continues to dominate the world of derivatives. It has derivatives contracts tied to $\$ 90$ trillion of underlying securities. Of that, $\$ 10.2$ trillion are credit-derivatives contracts. Those mind-boggling totals are somewhat misleading. They reflect what is called the "notional" amount in the world of derivatives, based on the underlying amount of the contract, not its current value. When offsetting contracts are taken into account, that figure is whittled down to a much smaller - though still enormous - $\$ 109$ billion of derivatives, of which $\$ 26$ billion are credit derivatives.

\section{Subprime Mortgage Crisis}

The subprime mortgage crisis is an ongoing real estate crisis and financial crisis triggered by a dramatic rise in mortgage delinquencies and foreclosures in the United States, with major adverse consequences for banks and financial markets around the globe. The crisis, which has its roots in the closing years of the 20th century, became apparent in 2007 and has exposed pervasive weaknesses in financial industry regulation and the global financial system $[18,19]$. The value of USA subprime mortgages was estimated at \$1.3 trillion as of March 2007, with over 7.5 million first-lien subprime mortgages outstanding. The value of all outstanding residential mortgages, owed by USA households to purchase residences housing at most four families, was US\$9.9 trillion as of year-end 2006, and US $\$ 10.6$ trillion as of midyear 2008. By August 2008, 9.2\% of all U.S. mortgages outstanding were either delinquent or in foreclosure. By September 2009, this had risen to 14.4\%. Between August 2007 and October 2008, 936,439 USA residences completed foreclosure.

\section{Banking Closure Crisis}

A bank run occurs when a large number of bank customers withdraw their deposits because they believe the bank is, or might become, insolvent. As a bank run progresses, more people withdraw their deposits, the likelihood of default increases, and this encourages further withdrawals. This can destabilize the bank to the point where it faces bankruptcy [20].

The year 2010 has also started on a bad note for the US banking industry with eleven banks closing down so far this year, in the first two weeks which bring the total banks closure up to 140 . The US regular had come out with a list of over 450 banks which were below the standard capital adequacy norms, in August 2009. Historically, at least 20\% to $25 \%$ of these banks go bankrupt in the subsequent year. So we can expect the total bank closures in 2010 to be at least 90 to 130 banks.

\subsection{U.S. Bailout, Stimulus Pledges Total $\$ 11.6$ Trillion}

In its first effort at quantitative easing, the Fed in 2009 and early 2010 bought $\$ 1.25$ trillion in mortgage-backed securities, and another $\$ 200$ billion in debts owed by government-sponsored enterprises, primarily Fannie Mae and Freddie Mac, and completed the purchases in March. The Fed had planned to allow the size of that portfolio to shrink gradually over time as the debts matured [21].

The Federal Reserve Wednesday announced its latest effort to spur economic growth: a plan to purchase up to $\$ 600$ billion of government bonds through June 2011. It wants to lower interest rates, in the hopes that doing so will loosen the supply of credit and spur more economic activity. The central bank's main tool for reducing rates is to slash the short-term overnight lending that banks charge to one another, the so-called Federal Funds rate. Bring short-term rates down, and long-term rates tend to follow. In normal times, that's as far as the Fed usually goes. In the past three years, the Fed has reduced the Fed Funds target rate 10 times, from 5.25 percent to between zero and .25 percent. It's been at that extremely low level since the fall of 2008.

The following table details how the U.S. government has pledged more than \$11.6 trillion on behalf of American taxpayers over the past 19 months, according to data 
compiled by Bloomberg. It Includes a $\$ 787$ billion economic stimulus package. The Federal Reserve has new lending commitments totaling \$1.8 trillion. It expanded the Term Asset-Backed Lending Facility, or TALF, by $\$ 800$ billion to $\$ 1$ trillion and announced a $\$ 1$ trillion Public-Private Investment Fund to buy troubled assets from banks. The U.S. Treasury also added $\$ 200$ billion to its support commitment for Fannie Mae and Freddie Mac, the country's two largest mortgage-finance companies [22]. Table 3 details are as by Feb 24, 2009.

\section{US Debt Crisis and Volatile Fractional Banking}

The U.S. government does not issue U.S. currency - the Federal Reserve does. The Federal Reserve is a private bank owned and operated for profit by a very powerful group of elite international bankers. If you will pull a dollar bill out and take a look at it, you will notice that it says "Federal Reserve Note" at the top. It belongs to the Federal Reserve. The U.S. government cannot simply go out and create new money whenever it wants under our current system. Instead, it must get it from the Federal Reserve. So, when the U.S. government needs to borrow more money it goes over to the Federal Table 3: Sample of 2009 US Bailout and Returns (in Billions)

Reserve and asks them for more called Federal Reserve Notes. So that is how the U.S. government gets more green pieces of paper called "U.S. dollars" to put into circulation. But by doing so, they get themselves into even more debt which they will owe even more interest on. So every time the U.S. government does this, the national debt gets even bigger and the interest on that debt gets even bigger.

As you read this, the U.S. national debt is approximately 12 trillion dollars, although it is going up so rapidly that it is really hard to pin down an exact figure. So how much money actually exists in the United States today? Well, there are several ways to measure this.

Table 3. US bailout sample.

\begin{tabular}{ccc}
\hline Sector & Outlay & Returned \\
\hline Total (Billions) & $\$ 447.76$ & $\$ 75.33$ \\
Capital Purchase Program & $\$ 204.55$ & $\$ 70.56$ \\
General Motors, Chrysler & $\$ 79.97$ & $\$ 2.14$ \\
American International Group & $\$ 69.84$ & $\$ 0.00$ \\
$\begin{array}{c}\text { Making Home Affordable } \\
\text { Investment Bank of } \\
\text { America }\end{array}$ & $\$ 23.40$ & $\$ 1.13$ \\
Targeted Investment & $\$ 20.00$ & $\$ 0.00$ \\
Citigroup & $\$ 20.00$ & $\$ 0.00$ \\
Term Asset-Backed Loan & $\$ 20.00$ & $\$ 0.00$ \\
\hline
\end{tabular}

Total world wealth is somewhere around \$160 trillion, and total world debt, public and private, is about the same amount, \$150 trillion. Current world GDP is about \$60 trillion. More and more, the debt is beginning to drag the world down into a dark hole of endless interest payments and more new debt to service old debt. By 2010, total debt of the US Federal Government will finally reach one year of GDP, about 15 trillion dollars. Japan is well beyond that already and European countries like Greece, Spain, Ireland and Iceland are close to financial chaos due to overwhelming amounts of debt.

So will the U.S. government come to the rescue? The U.S. has allowed the total federal debt to balloon by $50 \%$ since 2006 to $\$ 12.3$ trillion. During the administration of President George W. Bush, the total debt increased from $\$ 5.6$ trillion in January 2001 to $\$ 10.7$ trillion by December 2008, rising from 54\% of GDP to 75\% of GDP. During March 2009, the Congressional Budget Office estimated that public debt will rise from $40.8 \%$ of GDP in 2008 to $70.1 \%$ in 2012 [23].

The total debt is projected to continue increasing significantly during President Obama's administration to nearly $100 \%$ of GDP. The 2010 U.S. budget indicates annual debt increases of nearly $\$ 1$ trillion annually through 2019, with an unprecedented \$1.0 trillion debt increase in 2009. By 2019 the U.S. national debt will be $\$ 18.4$ trillion, approximately 148\% of 2009 GDP, up from its approximately 80\% level in April 2009. Further, the subprime mortgage crisis has significantly increased the financial burden on the U.S. government, with over $\$ 10$ trillion in commitments or guarantees and \$2.6 trillion in investments or expenditures as of May 2009, only some of which are included in the budget document. The U.S. also has a large trade deficit, meaning imports exceed exports. Financing these deficits requires the USA to borrow large sums from abroad, much of it from countries running trade surpluses, mainly the emerging economies in Asia and oil-exporting nations.

- U.S. official gold reserves, totaling 261.5 million troy ounces, have a book value as of 30 November 2009 of approximately $\$ 11$ billion, vs. a commodity value as of 17 December 2009 of approximately $\$ 288.5$ billion.

- The Strategic Petroleum Reserve had a value of \$69 billion as of December 2009, at a Market Price of \$104/barrel with a \$15/barrel discount for crude.

- Total U.S. household debt, including mortgage loan and consumer debt, was \$11.4 trillion in 2005.

- By comparison, total U.S. household assets, including real estate, equipment, and financial instruments such as mutual funds, was \$62.5 trillion in 2005.

- In 2008, \$242 billion was spent on interest payments servicing the debt, out of a total tax revenue of $\$ 2.5$ trillion, or $9.6 \%$. Including non-cash interest accrued 
primarily for Social Security, interest was $\$ 454$ billion. Total U.S Consumer Credit Card revolving credit debt was $\$ 931.0$ billion in April 2009.

- Total third world debt was estimated to be $\$ 1.3$ trillion in 1990.

- The global market of all stock markets of the World Federation Exchanges was $\$ 32.5$ trillion by end of 2008 .

\section{Greece Debt Crisis and Goldman Sachs Financial Derivatives}

The crisis in Greece poses the most significant challenge yet to Europe and its common currency, the euro, and its economic unity. Greece owes the world $\$ 300$ billion, and major banks are on the hook for much of that debt.

European governments and the International Monetary Fund committed to pull Greece back from the brink of default, agreeing on Euro110 Billion in emergency loans on the condition Athens make painful budget cuts and tax increases. The rescue is aimed at keeping Greece from defaulting on its debts and preventing its financial crisis from infecting other indebted countries just as Europe is struggling out of recession.

In 2001, just after Greece was admitted to Europe's monetary union, Goldman Sachs helped the government quietly borrow billions. That deal, which was hidden from public view because it was treated as a currency trade rather than a loan, helped Athens to meet Europe's deficit rules while continuing to spend beyond its means. Such financial derivatives, which are not openly documented or disclosed, add to the uncertainty over how deep the troubles go in Greece and which other governments might have used similar off-balance sheet accounting.

The 2001 transaction involved a type of derivative known as a swap. One such instrument, called an interestrate swap, can help companies and countries cope with swings in their borrowing costs by exchanging fixed-rate payments for floating-rate ones, or vice versa. Another kind, a currency swap, can minimize the impact of volatile foreign exchange rates.

Aeolos, a legal entity created in 2001, helped Greece reduce the debt on its balance sheet that year. As part of the deal, Greece got cash upfront in return for pledging future landing fees at the country's airports. A similar deal in 2000 called Ariadne devoured the revenue that the government collected from its national lottery. Greece, however, classified those transactions as sales, not loans, despite doubts by many critics. In 2002, accounting disclosure was required for many entities like Aeolos and Ariadne that did not appear on nations' balance sheets, prompting governments to restate such deals as loans rather than sales.

In 2005, Goldman sold the interest rate swap to the National Bank of Greece, the country's largest bank. In
2008, Goldman helped the bank put the swap into a legal entity called Titlos. But the bank retained the bonds that Titlos issued. While Greece did not take advantage of Goldman's proposal in November 2009, it had paid the bank about $\$ 300$ million in fees for arranging the 2001 transaction. Financial derivatives Instruments developed by Goldman Sachs (JPMorgan Chase) are raising questions about Wall Street's role in the world's latest financial drama.

\section{Iceland Crisis: Credit and Fractional Banking Problems}

On November 19, 2008, Iceland and the International Monetary Fund (IMF) finalized an agreement on a $\$ 6$ billion economic stabilization program supported by a $\$ 2.1$ billion loan from the IMF. Following the IMF decision, Denmark, Finland, Norway, and Sweden agreed to provide an additional $\$ 2.5$ billion. Iceland's banking system had collapsed as a culmination of a series of decisions the banks made that left them highly exposed to disruptions in financial markets.

The collapse of the banks also raises questions for leaders and others about supervising banks that operate across national borders, especially as it becomes increasingly difficult to distinguish the limits of domestic financial markets. Such supervision is important for banks that are headquartered in small economies, but operate across national borders. If such banks become so overexposed in foreign markets that a financial disruption threatens the solvency of the banks, the collapse of the banks can overwhelm domestic credit markets and outstrip the ability of the central bank to serve as the lender of last resort.

A combination of economic factors over the early to mid-2000s led to Iceland's current economic and banking distress. In particular, access to easy credit, a boom in domestic construction that fueled rapid economic growth, and a broad deregulation of Iceland's financial sector spurred the banks to expand rapidly abroad and eventually played a role in the eventual financial collapse. Iceland benefitted from favorable global financial conditions that reduced the cost of credit and a sweeping liberalization of its domestic financial sector that spurred rapid growth and encouraged Iceland's banks to spread quickly throughout Europe.

In 2004, Iceland's commercial banks increased their activity in the country's mortgage market by competing directly with the state-run Housing Financing Fund (HFF), which had been the major provider of mortgage loans. In contrast to the Housing Financing Fund, the commercial banks began offering loans with lower interest rates, longer maturities, and a higher loan to value ratio. Also, the banks did not require a real estate pur- 
chase as a precondition for a loan, which made it possible for homeowners to refinance existing mortgages and to access the equity in their homes for consumption or investment purposes.

Iceland has five commercial banks: Glitnir, Kaupthing, Nyi Landsbanki, Straumur Investment Bank, and Icebank, which serves as the clearing house for the 20 locally-run savings banks. The three largest banks, Kaupthing, Landsbanki, and Glitnir, have total assets of more than $\$ 168$ billion, or 14 times Iceland's GDP. Iceland also has 20 savings banks, with assets at the end of 2007 valued at $\$ 9$ billion.

\section{Recommendations and Conclusions}

In this paper the principle of conservation of physical money has been introduced. Defining commodity and fiat money as well as gold standard is presented. Major causes of the international financial crisis such as fractional banking system financial derivatives and lacking a commodity money standard are discussed. Examples of international crisis such as mortgage crisis, credit default crisis, debt crisis, financial derivative crisis, banking closures all resulted from the violation of conservation of physical money. The international financial system is very complex and fixing it needs a major sacrifice. The world Today's reserves wealth of Gold, Silver and Copper is estimated by 8.63 Trillion US\$ compared to 4.3 Trillion US\$ in Currencies. And global outstanding derivatives have reached 1.14 quadrillion dollars. Taking no action of implementing comprehensive overhaul maintenance of the financial system, the world will witness the collapse of such an existing system and a rush to reserve gold and silver.

The proposed solution to avoid such an international financial Tsunami is proposed as follows:

1) Cancelation of Fractional Banking System.

2) Implementation Zero Interest.

3) Applying Commodity Gold/Silver Standard

4) Dropping the Overvalued Debts

5) Prohibiting Credit Swap

6) Freezing all Derivatives and re-evaluate values

7) Enforcing Ethical Financial Auditing

\section{REFERENCES}

[1] A. V. Deardorff, "Deardorff's Glossary of International Economics," Department of Economics, University of Michigan, Michigan, 2008.

[2] F. S. Mishkin, "The Economics of Money, Banking, and Financial Markets (Alternate Edition),” Addison Wesley, Boston, 2007.

[3] A. O’Sullivan and M. S. Steven, "Economics: Principles in Actino,” Pearson Prentice Hall, Upper Saddle River, New Jersey, 2003.
[4] W. S. Jevons, “XVI: Representative Money,” Money and the Mechanism of Exchange, 2009.

[5] P. D. Michael, F. L. David and M. G. Peter, "Bretton Woods II Still Defines the International Monetary System," National Bureau of Economic Research, 2009.

[6] D. Yergin and S. Joseph, "Nixon Tries Price Controls," Commanding Heights, 1997.

[7] BBC News, “China Presses G20 Reform Plans,” 2009.

[8] AFP, "UN Panel Touts New Global Currency Reserve System,” 2009.

[9] M. Brian, "Chavez to Seek Arab Backing for PetroCurrency,” Associated Press, 2010.

[10] Central Banks and Official Institutions World Gold Council, 2009.

[11] US Geological Survey, "Mineral Commodities Summaries,” 2006.

[12] U. Bardi and M. Pagani, "Peak Minerals," Posted on http://www.theoildrum.com/node/3086.

[13] M. Artzrouni, "The Mathematics of Ponzi Schemes," Mathematical Social Sciences, Vol. 58, 2009, pp. 190-201. doi:10.1016/j.mathsocsci.2009.05.003

[14] K. Hamlin, "Mobius Says Derivatives, Stimulus to Spark New Crisis," Bloomberg News, 2009.

[15] IMF, “World Economic Outlook,” 2009.

[16] A. van Duyn, "Worries Remain Even after CDS CleanUp,” The Financial Times, 2009.

[17] B. Colin, "The Truth about Credit Default Swaps," CNN/Fortune, 2009.

[18] J. Lahart, "Egg Cracks Differ in Housing, Finance Shells," Wall Street Journal, 2007.

[19] B. S. Bernanke, “The Subprime Mortgage Market," Chicago, Illinois, 2007.

[20] L. Laeven and F. Valencia, "Systemic Banking Crises: A New Database,” IMF WP/08/224. International Monetary Fund, 2008.

[21] “Fed to Buy U.S. Debt,” New Yourl Times, 2010.

[22] “US Congress Passes Stimulus Plan,” BBC News, 2009.

[23] F.Y., "Budget Historical Tables,” 2010, pp. 127-128. 